\title{
Chapter 10 \\ Daughters of the Hills: Gendered Agricultural Production, Modernisation, and Declining Child Sex Ratios in the Indian Central Himalayas
}

\author{
Pernille Gooch
}

Keywords India - Womens role in agricultural production - Gendered division of labour $\cdot$ Crop production

In her seminal findings on female neglect in rural North India, based on the census from 1961 and literature studies, the anthropologist Barbara Miller detected a strong correlation between neglect of daughters, agricultural production and the cost of marriage (Miller 1981). She also found significant regional and social variations between the South and the North. In examining studies from throughout India, she observed a pattern in which exceedingly high cost of marriages of daughters among upper social groups in the North corresponded with son preference and high female juvenile mortality, whereas the figures for the South indicated much more equal conditions. With agricultural production and the demand for female labour as the motivating factor, she observed a North/South dichotomy, expressed as "masculinism" in the North, with dry-field plough cultivation and a low demand for female labour, and "feminism" in the South where swidden and wet rice cultivation accompanied a high demand for female labour (Miller 1981, p. 27 f.). Ester Boserup discovered a similar pattern dividing the subcontinent in female participation in farming, with much higher female participation in the South than in the North (Boserup 1970, p. 59 f.). Miller further found that the Himalayan region of Northern India did not fit the geographical dichotomy between the North and the South. Her study showed that, although geographically belonging to the North, the mountainous region was in some cultural ways more akin to the South, including a high participation of women of cultivator families in agricultural work in the Himalayan area (Miller 1981, p. 108; cf. Agarwal 1994, p. 358).

Miller hoped that by using the 1961 census data to expose the "strong effects of culture not only on female roles and status but also on female survival itself" her results could assist in raising female status (Miller 1981, p. 15). However, 40 years later, and after a decade of rapid economic growth, the 2001 Census of India

\footnotetext{
"Do not abort me. I have a worth. I can be useful." Indian advertisement advocating the worth of the female foetus

P. Gooch $(\square)$

Human Ecology Division, Lund University, Sölvegatan 12, 22362 Lund, Sweden

e-mail: pernille.gooch@hek.lu.se
} 
data indicated an even bleaker scenario for daughters in India. The Indian census counts "missing girls", not "surplus boys", and according to census results, the sex ratio of the 0-6 age group had declined at a highly disturbing pace since 1991 , from 945 girls for 1,000 boys in 1991 to 927 girls for 1,000 boys in 2001, although the overall sex ratio had increased slightly. Thus, contrary to expectations, we find that, despite heightened consciousness regarding the problem, what had occurred was not the raising of female status and the normalising of juvenile sex ratios but rather quite the contrary. These results revealed marked declines in areas and social groups that earlier showed more equal conditions, with the signs of modernisation, such as urbanisation and female literacy, having a strong negative correlation to the Child Sex Ratio (CSR).

Much has been written regarding gender, patriarchy and unbalanced CSRs in Northern India; however, this discussion is usually restricted to the northern plain area. Here, we will examine more closely the state of Uttarakhand in the Himalayan region of Northern India, where, as mentioned above, declining juvenile sex ratios are a relatively recent phenomenon. This should provide opportunities for studying an old phenomenon in a modern context. The Census of 2001 showed an alarming decline in the CSR in Uttarakhand, down from 948 in 1991 to 906 in 2001. In this northern mountain state, rapidly declining juvenile sex ratios are a phenomenon of the 1990s, which also have wide regional variation. Using the CSR as an indicator, the question is as follows: how can we understand these disturbing figures, and to what extent can the work of Ester Boserup aid us in the task?

\subsection{Contrasting Case Studies}

The study was conducted through contrasting case studies in rural Uttarakhand between 2004 and 2009. Beginning at the tehsil level (an administrative subdivision of a district), we first selected the tehsil with the lowest CSR (low number of girls to 1,000 boys) and then, for comparison, also the tehsil with the highest CSR (high number of girls to 1,000 boys). The tehsils thus selected were Pithoragarh tehsil in the eastern part of Uttarakhand, with only 855 girls for 1,000 boys, and Puraula tehsil in the northwest, chosen for contrast, which had an even number of boys and girls, $1,000 / 1,000$. Detailed surveys of 25 households having at least one child between the age of zero and six were then performed in each tehsil. This was followed by several field visits during which agro-ecological conditions were also studied.

Within Puraula tehsil, which is very large and thinly populated, both the survey and the case study were performed in villages in Mori Block (subdivision of the tehsil), one of the most marginalised parts of the region. Mori, stretching all the way from the middle mountains to the glaciers, is characterised by small terraced villages with very high CSR, many with more than a thousand girls to a thousand boys. In Pithoragarh tehsil, situated in the middle ranges, the study was performed in one of the large rural villages in Bin Block, here called "Bin Village", situated just outside the town of Pithoragarh (the district headquarters) and thus in the most central part 
of the tehsil. The selection of "Bin Village", with a CSR that is below the average of the tehsil as a whole, added further contrast to the study.

Although the indicator was the CSR, what we found were two areas at different stages of modernisation and of agrarian transition. By choosing the rural extremes within the tehsils for further study, we could thus follow the process of modernisation from the areas closest to urban Pithoragarh in rural Bin Block in the hilly south-eastern part of the state to the villages closest to the glaciers in Mori Block in the north-western part. Bin Village is apparently "modern" in regard to integration into the market, infrastructure, and new possibilities of employment, whereas Mori appears to be "traditional", marginalised with poor infrastructure, and still completely dependent on mixed agriculture. Although Mori is characterised by intensification and expansion of agriculture, primarily based on female labour, we also found that women in Bin work in cultivation, quite in accordance with the pattern for the mountains; here, however, female labour occurs simultaneously with land abandonment and male out-migration.

A question posed is whether the difference in the CSR figures could be just due to the distance from facilities for pre-natal diagnostic and sex-selective abortion. Although new medical technology is important, the underlying picture is not so simple. Our findings indicate that behind the differences in CSRs we find a much more complex picture of the changing social, economic, and cultural contexts through which gender is constructed, contexts that guide whether to raise a daughter.

\subsection{Uttarakhand-Dominated by Female Farming Systems}

In 2000, after many years of agitation, the central part of the Indian Himalayas, formerly known as the UP hills, severed its ties with Uttar Pradesh-India's largest state, situated in the densely populated upper Gangetic plain region-and was constituted as Uttarakhand, the 27 th state of the Indian Republic. Although there are some large towns in the areas closest to the plains, the economy of the state is still predominantly agrarian, and more than $75 \%$ of the population is rural. Until the year 2000 , this was the most marginalised part of Uttar Pradesh, and a place primarily forgotten by politicians and agricultural developers.

Traditionally, the North/South dichotomy of agricultural production and the demand for female labour divided the state of Uttar Pradesh, characterised by the masculinisation of labour in the plain areas below and feminisation in the hill districts. Boserup (1970, p. 63) describes Uttar Pradesh as one of the Indian states with a most restrictive attitude towards work by women outside of the domestic sphere. She also found it to have one of the lowest rates of participation of female family labour in their own fields. According to Miller, Uttar Pradesh was typical also in another respect-as one of the northern states with a high prevalence of son preference and where the use of female infanticide was common among upper castes. She further found that also in this respect a dichotomy existed between the plain area and the UP hills, in which the latter appeared to be exempt from the 
practice (Miller 1981, p. 54). We thus find that Pahari (mountain) women have had a much stronger position in society than women in the plains area below. Today, Uttarakhand is still dominated by female farming systems where, contrary to the situation in Uttar Pradesh below, essentially all work is performed by female labour. The contribution of men in agriculture is generally reduced to walking behind the bullocks when ploughing the fields and marketing the produce.

In Uttarakhand, policies for the development of farming have primarily emerged following separation in 2000. The backbone of economic activity in the hills has traditionally been mixed small-scale agricultural ventures depending primarily on local input and producing for subsistence rather than for the market. Characteristic of the agricultural systems in the mountains has also been a system of mixed millet farming with a high degree of domesticated biodiversity of both plants and livestock and dependence on forest resources. This scenario is now changing with, on one hand, the commercialisation of agriculture and, on the other, migration and diversification of occupations in which agriculture loses its importance to salaried employment outside of the village. This is complemented by a "Money order economy" fuelled by large-scale migration of younger men to the plains for jobs in the armed forces, government or the private sector. Development in the state appears to affect women - and especially female children — negatively. Although the overall sex ratio in Uttarakhand increased from 936 to 964 between 1991 and 2001, the CSR, as we observed above, fell drastically. However, as we will discuss further below, there are still great regional differences.

\subsection{Low CSR-Bin Block, Pithoragarh Tehsil}

Although Pithoragarh tehsil has the lowest sex ratio in Uttarakhand in the 0-6 years range, with an average of 855 girls to 1,000 boys, there is a clear rural/urban divide, with a rural CSR of 867 and an urban CSR of only 819 . The tehsil is dominated by Pithoragarh, the largest town of the district, situated in the Soar valley and surrounded by hills. Today, Pithoragarh is a modern town with good infrastructure including easy access to medical facilities, good teaching institutions and a well-connected transport network. Bordering Nepal, it is also an important trade centre. This has provided new opportunities for work outside of agriculture, especially for males. For Pithoragarh tehsil, the most modernised portion of the district, this influx of funds from outside has caused a decline in the importance of agricultural production, which is now marginalised, based on female labour and mainly conducted for subsistence. With greater exposure to "modern" lifestyles, new values have also been accepted, leading to reduced fertility and family size. As more children now survive, two children have become the norm for the young generation of parents. In Bin Village, respondents stated that they could only afford a small family. Although the ideal family is one son and one daughter, in practice, at least one son is a must, whereas a daughter is optional. In our survey, this is generalisable to a preference for either one child of each sex or for two sons. Although all individuals interviewed denied that they themselves 
used ultrasound technology to abort girl foetuses, which is strictly forbidden, they all knew that the technology existed and said that they were sure that many families in the area used it.

Generally, the preference for a son was articulated in statements from women such as "We must have at least one boy", or "we cannot afford more than one daughter due to high marriage expenses". They also said "a daughter will be the wealth of another home", or "our in-laws are the biggest problem, they are the ones who want the boys most". In the study, we found no difference in son preference between high and low caste respondents in the village.

Meena, a 26 year old mother belonging to the Scheduled Caste, with two daughters and one son, strongly expressed the seriousness of discrimination against girls:

Girls have to suffer everywhere: They can't do anything freely. They are killed or burned by in-laws for not bringing dowry. Only if we give her a good dowry will she get a good home. If something happens where will girls go, to whom will they ask for help? Daughters should be educated. If the husband forces her out of the house she should have some weapon [the possibility of a job] in her so she may fill the stomach of herself and children.

She articulated a view of the horrendous fate of women that appeared to be shared by most of the women in the village. Many expressed that the life of a woman was hard, especially following marriage. They told of cases of dowry deaths, and a group of women went so far as to express that "marriage is barbaric". Young girls spoke of wedlock as their inevitable, but frightening, destiny. This was even more terrifying, as girls were generally married in their late teens or early twenties by arranged marriage into extended families far away from their home village. This entails, as stated by Meena above, that in case of problems with in-laws, the girl must face it alone without support from her own kin. The hope for this mother, as for many others, consisted in attempting to provide a good dowry and education for her daughters. There appeared to be no differences in money spent (or planned) for the education of sons or daughters.

The education of girls did not seem to result in working careers for women. Although many young wives in the village were educated-many as much as their husbands-most women, young and old, spent their days with domestic and agricultural work. Many parents stated that they would like to educate their daughters so they could obtain a government or office job. However, in our study of young rural families, only two women, both teachers with teaching husbands, had work outside the own farmstead. Other young mothers with high school exams or bachelor degrees worked as cultivators like the rest. Although unmarried girls act as farm labour at home, neither high nor low caste families would allow their daughters to do labour outside the family. A son may go out to work anywhere to support the family. For a girl, this is not possible. Doing labour outside the home was not considered secure for females. In Bin Village, security for daughters was a major issue and, as articulated by Meena above, girls were not permitted to act freely. As a rule, neither girls nor women are allowed to go out alone anywhere. Women stated that they could not freely go to the market in Pithoragarh only a couple of kilometres away. If they wanted to purchase anything for the household, they had to ask a male member of 
the family. From the age of 15, girls are strictly supervised, whereas their brothers are free to move around. Kamla, an educated high caste mother of two young sons, articulated it thus:

Girls in the cities can do many things. However, the society in the village is very backward. If a girl behaves as a boy, then she is seen as the worst girl of the village. Dowry and security are the two main things in India for daughters.

A mother with two daughters and one son articulated her concern thus:

Daughters cannot be left alone. They need security. One guardian should always be there with them. If something happens to them the whole image of the family will be merged in mud. People want a chance to speak bad about girls. They can't go alone to cut grass because of fear of bad and drunken boys. They go in groups. If they are seen alone nobody will marry them. If she marries on her own she will be sent out of the village and her parents will cut off all relations with her.

Another educated mother with one daughter and two sons stated that "girls need more care. The parents' image depends on them." However, she also suggested change and new possibilities for girls: "Today girls can do anything that boys do. If they are well mannered and strict in their character they can go higher than boys." What most respondents expressed, though, was that "daughters are difficult" and that "security and dowry" are the primary issues concerning daughters. Parents thus must keep their daughters safe in an increasingly insecure and changing world until they can pass them on to a new family together with a dowry, the gift that, hopefully, will ensure that they married into a good family who will treat them well. To pay dowry, they explained: "If we do not have the money, we will sell a field, we will take a loan, we will do anything to pay it".

Although most of the women stated "cultivator" as their primary occupation, farming here has lost its economic importance to a great extent. Agriculture is primarily for subsistence, and there is hardly any surplus to sell. For many families, the produce does not even cover the needs of the household, and supplements must be bought in the market. One man went so far as to say that continuing to cultivate is counterproductive. He stated that they only continue because they had always done so; it was part of their tradition to grow crops and keep a cow, but in reality, it would save both time and money to stop farming. High caste men do not work in cultivation. Male tasks, such as ploughing, were performed by men from the Scheduled Caste. However, even in the low caste portion of the village, all cultivation apart from ploughing is done by women and girls. Agriculture is performed in the valley, whereas many terraces on the hillsides are now abandoned. Formerly, there were fruit orchards, more crops and higher yields. Farming is now less intensive, and landholdings are small and fragmented. The main crops are wheat, rice and pulses, but yields are low as the land is stony and not irrigated. Women herd livestock, such as sheep, goats, buffaloes and cows, in the scrub forest surrounding the village. Fewer animals are kept now because of the labour involved. No capital is returned to farming.

As we observed, women have access to land; however, the land does not generate any cash, and they do not have the economic means for new technology or input into agriculture, such as high yielding seeds and fertilisers. This is a scenario that very well 
fits into Boserup's feminisation of agriculture (1970, p. 44). Keeping fewer animals also has the consequence that there is less manure for the fields and not so much to harvest. This is a break with the traditional farming system with a high degree of cultivated biodiversity, built on livestock, kept in forests and on fallows, producing fertilisers for the fields. Women said that they work less in agriculture now than they did earlier and spend more time on domestic work. This is quite in accordance with a comment by Mendhapurkar: "The better the economy, the greater the domestication of women and the lesser their role in direct economic activities" (Rajalakshmi 2005, p. 3). What we found in Bin Village was that women still cultivate, but their work has lost economic importance. A male student from a household with two sons and no daughters bluntly expressed that the contribution of women to the household is no longer considered important: "We cannot afford girls because girls are not productive".

However, this has not been the historic status of women in the Himalayas. People stated that dowry is a recent phenomenon, introduced as part of a general modernisation process. Traditionally, a young bride would just bring a box of household items to her new home. This is well expressed by a middle-aged woman: "Earlier a girl was given household items in order to start her new life, now the in-laws demand consumer items such as refrigerator or TV as well as cash". So the development has gone, from a gift to a daughter leaving home, to a demand for expensive commodities, not for the daughter, but for her in-laws. Elderly Brahmins in the area said that in former times they used to pay for a bride. As stated by Srinivas, bride price, otherwise recognised in the North as a practice only of poor and low caste communities, was widespread in the Himalayas, including among Brahmins, until World War II (Srinivas 1984, p. 18). Previously, farming was vital for the economic survival of the household. Although women have always performed most of the labour, both sexes were actively engaged in agriculture.

However, what is examined here is the extreme: a farming village on the outskirts of the town of Pithoragarh. In the villages of the tehsil that are situated further away from urban Pithoragarh, farming is still economically important, and there you will still find mixed farming systems, both for the market and for subsistence, along with higher CSR. As stated previously, Pithoragarh tehsil had a rural CSR of 867 and an urban CSR of only 819. The CSR of 821 in Bin Village was thus much more similar to that of the urban area.

For comparison and contrast, we now turn to the opposite corner of Uttarakhand, an area of the state where agriculture is still the most important economic venture and where the attitude towards daughters — and women in general—is very different.

\subsection{High CSR-Mori Block, Puraula Tehsil}

Using the CSR as the indicator, Puraula tehsil in Uttarkashi District stands at the opposite end of the spectrum from Pithoragarh tehsil, with an equal number of girls and boys $(1,000 / 1,000)$, the highest ratio at the tehsil level in the state. The two 
tehsils also stand in contrast with respect to female literacy, with Pithoragarh at the top with a female literacy rate of 72.5 , whereas Puraula is at the bottom with a female literacy rate of only 38.5, approximately half of the male literacy rate, which is 73.7 . This further demonstrates that development in the form of education and reduction of the gender gap in literacy does not automatically lead to more equal conditions for women and girls.

Puraula tehsil, which is purely rural, constitutes the north-western part of Uttarkashi district. Mori Block is the most inaccessible area of the tehsil. Although families are generally larger than in Bin, today, the two children norm has reached also this remote corner of the state. In addition, most parents here viewed an ideal family as having one child of each sex. The difference was that here we did not find the extreme son preference so prevalent in Bin. Parents in Mori expressed that an ideal family must have at least one daughter and one son. They formulated it by saying "Both girls and boys are necessary for a good family", and many mothers went so far as to say "We are happy for daughters. Daughters help us with our work. Boys are careless. They do not help". Fathers also expressed sentiments such as "Daughters are closer to parents than sons".

Although Pithoragarh today is a busy infrastructural centre, the small township of Mori is literally at the end of the road. The landscape is mountainous, dotted with tiny hamlets with terraced fields, and many villages in the area can only be reached by a strenuous walk along narrow mountain paths. This means that most transport is still by human bearers or by pony or mule. Pithoragarh, close to Bin Village, has a whole range of modern medical and educational facilities, whereas Mori only has a small government hospital and no education after class twelve. Many villages and hamlets are also without modern conveniences such as electricity and telephone. In the outermost parts of the region, schools are only recently introduced, and many places have a high rate of female illiteracy. However, although Mori has a low rate of literacy for women, we found no present differences in education between daughters and sons. Most parents stated that they planned to educate both sons and daughters as "far as possible". Fathers and mothers expressed that they wanted their daughters to obtain a good education and "go into service" to find a better life. Although most grown women in our study in this area had no or only a few years of education, we did find that the three women with higher education in our survey all had qualified outside jobs, two as teachers and one as a social activist for a Non-Governmental Organisation (NGO). In Mori, we also met women leaders, something we did not do in Bin. What we found was that although men in Bin have left farming for other occupations, agriculture is still the most important work for both sexes in Mori.

In this remote part of the state, new job opportunities have not appeared; although young men do migrate to jobs in the plains, these are primarily low paid menial jobs due to the lack of educational facilities for higher studies. Modernisation in the region is expressed as intensification and an increasing dependence on market powers within agriculture, husbandry and horticulture. Fruit growing has been economically important in neighbouring Himachal Pradesh for several decades, but here it is part of the new agricultural developments introduced after Uttarakhand attained statehood. Although crops produced for the markets in the plains below are replacing traditional 
crops produced to sustain the household, women from cultivator families - and their daughters-do most of the farm work. What has changed is that men have taken over the new task of marketing the produce, which gives them control over the cash portion of the family economy. However, as the following incident demonstrates, women still manage subsistence farming for food security, and they still have a strong position in decision-making.

We were sitting with a group of villagers, mostly women, in one of the small mountain villages outside of Mori. The women, of all ages, were active in a local women's self-help group, and they were discussing the agricultural situation in the village. During the discussion, which became very heated, it was obvious that there was a clear difference in opinion between women and men on which agricultural strategy to follow. The primary concern of the women was securing foodstuffs to cook for the family meal, and they were of the opinion that this need was best met by sticking to long-established farming practices with high agro-biodiversity, using traditional crops. The men, in contrast, wanted irrigation so that they could grow marketable crops, such as potatoes, soybeans or new hybrids of wheat and rice, or the new variety of plum trees, supposed to give a bumper crop. Such a scene, in which men have contact with extension services and press for the introduction of modern methods, is quite in accordance with the findings of Boserup (1970, p. 45 f.). The result should be that women gradually lose out. Here, however, the women were still strong enough to maintain their position as the main agriculturists. For the time being, a compromise was struck in which the women grew food crops on the land surrounding the village using local seeds and natural fertilisers, thus securing most of the needs of the household. New crops from improved varieties of seeds were grown on forestland with chemical fertilisers for sale at the market. This forest was previously used as an integrated part of a more extensive cultivation practice including both the cultivation of crops and animal husbandry. Again, we can use Boserup to understand that land used for intensification was earlier used in more extensive systems (Boserup 1965).

Intensification of agriculture increases the work burden of women as they perform most of the added labour. Women grow food for the household and crops for the market as well as doing domestic work, the latter including strenuous and time consuming chores such as fetching water, collecting firewood and gathering fodder from the forest. Men plough, using bullocks, and sell the produce. However, even here, the negative influence of modernisation can be detected. The further one moves away from the single road connecting the area with the outside world, the more males, both men and boys, one will find doing farm work and helping with domestic work. Although men living close to Mori will gather there during the day playing cards and talking, men living further away can be found in the villages caring for young children or doing other domestic chores, while the women work in the fields. Older men, who were still active in farming, also confirmed that "idle men and boys" is a recent phenomenon. We also found more dependence on the market in the villages close to the road, with whole villages concentrating on a single crop, such as growing potatoes for the urban markets on the plains, and more dependence on subsistence further away, with more mixed millet farming, preserved biodiversity and traditional 
cropping patterns with annual periods of fallow. Periods of fallow have traditionally been times where women were relatively free from cultivation work. In addition, this changes as agriculture intensifies with modernisation and more crops are raised, quite in accordance with the findings of Boserup in The Conditions of Agricultural Growth. Women now must work longer hours, and their work becomes harder.

The fact that agriculture is essential to economic survival and that women perform most of the labour has added to the economic value of keeping daughters. As an elder man in one of the villages said "Earlier girls were married at a young age and sent to their in-laws for whom they worked. Now they are married later and they contribute with important labour at home before they leave". Thus, in former times girls were valuable because the in-laws, who would obtain a worker, paid a bride price to the family of the girl. Today, a daughter is valued as she gives part of her work capacity to her natal family before going to her in-laws. However, Mori differs from Bin in other ways than the economic importance of daughters and of women in general. Women and girls are generally seen as not only hardworking but also as industrious and doing well at their studies, whereas boys are seen to a greater degree as idle and careless in their work capacity and studies. As expressed by Chandri, a 23-year-old mother of two sons but without a daughter, "Boys are careless. They don't obey their parents. They help in ploughing but not much else. If I got a daughter, I would be happy. She would help me in my work." In Mori, most parents also viewed their daughters as more caring than their sons. Surendri, a 21-year-old pregnant mother with one son and one daughter said both she and her husband wanted another daughter because "girls are more caring and close to their parents". Brijmala, an older woman, reported that she felt emotionally closest to her daughter and continued: "Daughters are so much help, also after they go to their in-laws' house". As daughters are often married within walking distance, they can come back and help their own family in times of need. This works both ways; although parents in Bin felt powerless if a daughter was treated badly by her husband and in-laws, a young woman in Mori under similar conditions could rely on support from her natal family. As in Bin, neither low nor high caste respondents would allow their daughters to do menial labour for others, but they expressed support for educated daughters wanting to move away for a job elsewhere. Ashok, a 30-year-old Rajput man with one daughter and one son, expressed the concern for his daughter thus: "Daughters are closer to us than boys. We will provide everything for our daughter. I will educate her as well as my son and send her to a job wherever she wants". During fieldwork, we met cultivator families with educated, unmarried daughters who still supported their natal family economically after having migrated to jobs elsewhere. Rekha, a young Scheduled Caste woman with one daughter and two sons, expressed the concern of many parents: "We want to educate our daughter as far as possible. She will be able to stand on her own feet. She will not be like us".

The primary issues concerning daughters in Bin, "security" and "dowry", did not have the same significance in Mori. Although parents in Bin felt that unmarried girls should be under surveillance at all times in order to not give the family a bad name, parents in Mori said that they would not mind sending an educated daughter to a job somewhere else, even if she had to live alone. Although women from Bin Village 
did not go alone to the market in Pithoragarh a couple of kilometres away, women of all ages in the Mori area could be seen moving around alone anywhere: on a mountain path, in the forest, going to the temple or on the way to market, always moving, always busy. In Bin the family, and especially the mother, was blamed if a girl did not follow the social norms set for her behaviour. In those cases, the mother was seen as the real culprit as she could not control her daughter. We discussed this with a woman leader in Mori and asked her whether a mother would be blamed if a young girl ran away with her lover. She answered surprised: "How can you blame the mother? The girl did it of her own free will." According to respondents in Mori, dowry was not yet an important issue. Most respondents reported that it was usually neither demanded nor given. Beela, a 40-year-old Rajput woman with two sons and five daughters, had this to say about dowry: "Dowry has been introduced very recently. However, only those families that have money give dowry to their daughters. It is not demanded". In many other places in India, having five daughters and thus having to pay dowry for them would be considered a horrible fate, but that is not so here. In Mori, parents still present to a daughter the things needed in her new life: a bed, a water pot, and a box of household utensils. Although the dowry of consumer goods in Bin was for the in-laws, what they give here is a gift for the daughter-as it was in Bin previously. In Bin, dowry is demanded by in-laws; in Mori, it is still an offering from parents who can afford it. However, a change can also be observed here with modernisation and proximity to mainstream society. In the southern and more "developed" part of the region, we did meet parents worrying about how to pay dowry for their daughters.

When we first came to Mori, we were told that paying for a bride was a thing of the past, something that they, as modern people, had eliminated. However, as we went higher into the mountains and came closer to the glaciers, we found that bride price was still a cherished institution in outlying villages. In Mori, we also found several examples of love marriages in which parents eventually accepted the relationship and slaughtered a goat to sanction it. In discussions, women stated that a girl who was badly treated in the home of her in-laws could return to her natal home, and her parents would remarry her somewhere else; however, they also said that this practice was declining, as somebody "who was educated would surely not marry such a girl." Again, we observe a negative impact on women's rights from education and modernisation. We also asked women if they felt that they have power in their households and in their communities. In Mori, women generally claimed that they had power, whereas we observed that many women in Bin felt powerless.

\subsection{Discussion and Conclusion}

Many social scientists have argued that, with increasing welfare, education of women and economic development, the importance of factors such as son preference would decline. However, we found that "son preference" and its resultant "missing girls" had actually increased alongside signs of modernisation such as lower fertility and 
Table 10.1 CSR (Child sex ratio) and female literacy in Pithoragarh and Puraula tehsils. (Source: Indian Census 2001)

\begin{tabular}{|c|c|c|c|c|}
\hline Tehsil & CSR (0-6) & Total SR & Female literacy & Male literacy \\
\hline Puraula & $\begin{array}{l}1000 \\
\text { Highest CSR }\end{array}$ & 947 & $\begin{array}{l}38.5 \\
\text { Lowest female literacy }\end{array}$ & 73.7 \\
\hline Pithoragarh & $\begin{array}{l}855 \\
\text { Lowest CSR }\end{array}$ & 985 & $\begin{array}{l}73.3 \\
\text { High female literacy }\end{array}$ & 94.4 \\
\hline
\end{tabular}

increasing economic and social welfare (Larsen et al. 2010). Increasing demands for dowry combined with modern techniques of ultrasonography and amniocentesis, resulting in female foeticide, are often cited as the primary reasons for declining CSRs in modern India. However, as stated by Agnihotri (2001, p. 79): "Sex ratio patterns in India are complex and diverse. Their analyses have to be sensitive to this diversity in its spatial, social, cultural and economic aspects".

Although many reports of CSR in India draw their results from aggregates of literature studies, in this study, we examined the diversity of "spatial, social, economic and cultural aspects" in the hills of Uttarakhand through surveys combined with field visits over a 5-year period. Using the CSR as the primary indicator, we have compared two areas in the state of Uttarakhand in the Central Himalayas. Beginning at the tehsil level, we found a strong negative correlation between CSR and female literacy. Pithoragarh tehsil has one of the highest rates of female literacy in the state together with the lowest CSR, whereas Puraula has the highest CSR together with the lowest female literacy (see Table 10.1).

These results substantiate the findings of the 2001 Census that development in the form of education and shortening of the gender gap in literacy does not automatically lead to more equal conditions for women and girls; it may lead to the opposite, resulting in fewer girls being born. However, knowing that it occurs does not really explain why it occurs.

Following Barbara Miller and Ester Boserup, we then looked for the correlations between the "worth" of females and their participation in production. Miller (1981) related the worth of females to their importance in agricultural production as well as to cultural understandings and the cost of marriage. From her material from throughout India, she drew generalisations regarding the co-variation between Juvenile Sex Ratio (JSR) and Female Labour Participation (FLP). Her conclusion was that, where FLP is high, there will always be high preservation of female life, whereas where FLP is low, female children may or may not be preserved. Uttarakhand has traditionally been known for a high rate of FLP in agriculture, which is clearly discernible in Table 10.2, illustrating our case studies at the block level.

We found a high rate of feminisation of labour within cultivation in both areas. This is quite in accordance with what can be expected from rural areas in the hills of Uttarakhand. The figures yet again in themselves provided no real answers to the differences in CPS; instead, answers came from our comparative fieldwork.

We found that differences in the economic importance of agrarian production and the economic worth of women's labour, rather than the FLP as such, appear to 
Table 10.2 FLP (Female labour participation) in Bin block (rural) in Pithoragarh tehsil and Mori block in Puraula tehsil. (Source: Indian Census 2001)

\begin{tabular}{lllll}
\hline Block & $\begin{array}{l}\text { Total workers } \\
\text { Female }\end{array}$ & $\begin{array}{l}\text { Cultivators } \\
\text { Male }\end{array}$ & $\begin{array}{l}\text { Cultivators } \\
\text { Female }\end{array}$ & $\begin{array}{l}\text { Other workers (not cultivator or } \\
\text { household industries) Female }\end{array}$ \\
\hline $\begin{array}{l}\text { Mori Block } \\
\quad \text { (Puraula tehsil) }\end{array}$ & 46.8 & 71.5 & 88.9 & 3.5 \\
$\begin{array}{c}\text { Bin Block } \\
\text { (Pithoragarh tehsil) }\end{array}$ & 42.6 & 50.6 & 92.7 & 4.5 \\
\hline
\end{tabular}

influence the CSR. In both cases from Uttarakhand, we have agricultural systems dominated by household female labour, with the difference being that in Mori, farming is still essential for the economic survival of the household, both for subsistence and for the market, whereas in Bin, its importance is giving way to incomes from wage employment by the men of the household. Women work in both agriculture and domestic work, and they work hard. However, in Mori, women—and girls—are the backbone of economic survival for their communities. They are seen as industrious, and their efforts are also valued by men. In the villages outside Pithoragarh, the work of women in agriculture is given a low value by members of the community.

Using the CSR from 2001 as the indicator, we have thus compared two rural areas in Uttarakhand and found them to be at the two extremes in regard to the CSR and also at different positions of agricultural transition. At one end, we have the most remote parts of Mori, where we find cultivation with a high degree of biodiversity and dependence on natural resources, primarily for subsistence and still vital for the survival of the household; we then observe how farming for the market increases in importance with the intensification of agriculture, although subsistence farming continues, and finally how market farming takes over in the most central and wellconnected area of Mori block. Moving to Bin, we have observed how an earlier farming system, similar to the combined subsistence and market system emerging in Mori, now in the most central part, close to urban Pithoragarh, has given way to a low yielding, extensive subsistence system, now completely feminised, which has lost economic importance.

From the outskirts of urban Pithoragarh to the remotest part of Mori, we may also track the penetration of capital, consumerism and modern development. Pithoragarh is considered to be modern and progressive, whereas the remote area of Mori is seen as traditional and backwards. However, along the same journey, we may examine other phenomenon such as "son preference", "dowry", the "worth of a daughter", or "freedom of women" and find that here modernisation is related to son preference and discrimination against daughters, rising dowries demanded by in-laws, and hardened attitudes towards control of women. In contrast, backwardness and tradition relate to wanting and valuing daughters, dowry as a simple gift to a daughter and more freedom for women. This paints a picture of women as the losers in development—at least at this stage of transition.

Already in 1970, Ester Boserup drew attention to the fact that, in spite of the importance of women in agriculture, development processes and policies have been 
biased against females (Kanji et al. 2011). She recognised how sex roles were polarised by modern development "with men at the progressive end and women at the traditional end" (Boserup 1970, p. 44). We observe a final step in such a process in Bin Village, where men have opted out of agriculture for other employment and left the women with a low yielding production of food crops for household consumption. As explained by Boserup (Boserup 1970, p. 44): “. . . women who produce food crops for family use have no cash income for improving their farming techniques" with the result that "the female sector continued with traditional low-productivity methods". However, in Mori, we might detect the signs of modern agricultural development as detrimental to women. As we observed, men control the cultivation of cash crops, although completely dependent on female labour, whereas women control the cultivation of food for family consumption. Therefore, men can invest in market farming, whereas women continue to rely on input from natural resources, such as forest and meadows. We observe that "modernisation" has moved up the Himalayas from the plains below, following new transport networks, and it has now reached the middle hills.

Boserup has been criticised for looking positively at development and for seeing a linear progression in economic development (Kanji et al. 2011, p. vi). Today, we have lost much of the optimistic belief in progress. We have encountered the dark sides of modern growth, and the picture of possible future developments now emerging is much more complex. We are no longer certain of the answers regarding where we are going and what the future might bring. Negative effects of development include valuing everything in economic worth, even a daughter, together with the threat of natural catastrophes, such as climate change, erosion, flash rains, loss of biodiversity and deforestation. Positive effects include new interests in sustainability, in enhancing food security and in organic and holistic farming systems. However, the situation for the girl child in India still looks bleak. As expressed by Mazumdar and Sharma (2001, p. 24 f.) from the Centre for Women's Development Studies, we must recognise "the subordination of women as an advancing rather than a disappearing phenomenon to which the globalisation of economic activities has contributed enormously, undoing in the process much of the hard earned benefits offered by other aspects of modernisation". Their pessimistic view is corroborated by the Indian Census of 2011. Those data reveal that, in spite of a blooming Indian economy and a rising level of education, the outlook is worse for the girl child. Although there were 927 girls per 1,000 boys in India in 2001, that ratio has declined to an all-time-low on the national level of only 914 in 2011 . For Uttarakhand, it is even worse, with a nearly 20-digit slump down to only 886 girls for 1,000 boys. That is close to the figures for Pithoragarh, the tehsil with the lowest CSR in 2001. Uttarakhand as a whole is also following Pithoragarh in rising female literacy from $63.36 \%$ in 2001 to $70.7 \%$ in 2011. It thus appears that the development in the state continues to go the way of modern Pithoragarh. However, as this study shows, discrimination against female children is not an absolute given; it differs greatly even within the same region, and thus it may be changed. We can only hope for a future for the "daughters of the hills" that maintains the tradition in Uttarakhand of strong and free women and a wish for daughters, such as we still observe in the remotest part Mori. 
Acknowledgments I am very grateful to Laxmi Semwal for excellent data collection and for valuable discussions. I further want to thank Professor Neelambar Hatti and Dr Mattias Larsen for collaboration, Professor Aswini Nanda for valuable help with methodology, and two anonymous reviewers for useful suggestions. Thanks are due also to the Swedish Research Council for the funds that made the project possible.

Open Access This chapter is distributed under the terms of the Creative Commons Attribution Noncommercial License, which permits any noncommercial use, distribution, and reproduction in any medium, provided the original author(s) and source are credited.

\section{References}

Agarwal, B. (1994). A field of one's own: Gender and land rights in South Asia. Delhi: Oxford University Press.

Agnohotri, S. B. (2001). Unpacking the juvenile sex ratio in India. In V. Mazumdar \& N. Krishnaji (Eds.), Enduring conundrum: India's sex ratio. Essays in honour of Asok Mitra (pp. 36-72). Delhi: Rainbow Publishers.

Boserup, E. (1965). The conditions of agricultural growth: The economics of agrarian change under population pressure. Chicago: Aldine.

Boserup, E. (1970). Woman's role in economic development. New York: St. Martins Press.

Kanji, N., Tan, S. F., \& Toulmin, C. (2011). Introduction: Boserup revisited. In E. Boserup (Ed.), Woman's role in economic development (pp. v-xxvi). London: Earthscan.

Larsen, M., Hatti, N., \& Gooch, P. (2010). Intergenerational interests, uncertainty and discrimination: Declining child sex ratios in India. In T. V. Sekher \& N. Hatti (Eds.), Unwanted daughters: Gender discrimination in modern India (pp. 38-74). Jaipur: Rawat Publications.

Mazumdar, V., \& Sharma, K. (2001). Asok Mitra: A tribute. In V. Mazumdar \& N. Krishnaji (Eds.), Enduring conundrum: India's sex ratio. Essays in honour of Asok Mitra (pp. 13-27). Delhi: Rainbow Publishers.

Miller, B. (1981). The endangered sex: Neglect of female children in rural North India. Ithaca: Cornell University Press.

Rajalakshmi, T. K. (2005). A battle won. Frontline, 22(11). http://www.hindu.com/fline/ fl2211/stories/20050603003210100.htm. Accessed 23 Apr 2013.

Srinivas, M. N. (1984). Some reflections on dowry. Delhi: Oxford University Press. 